\title{
Ideal Corporate Criminal Liability for the Performance and Accreditation of Public Accountant Audit Report in Indonesia
}

Submitted 21/06/19, $1^{\text {st }}$ revision 13/07/19, $2^{\text {nd }}$ revision 25/09/19 accepted 24/10/19

\author{
Henry Dianto Pardamean Sinaga ${ }^{1}$, F.X. Adji Samekto ${ }^{2}$, Joni Emirzon ${ }^{3}$
}

\begin{abstract}
:
Purpose: The purpose of this study is to examine the true legal answers and the prescriptive legal solutions for the Indonesian public accountant legal liability and how it is included in the audit report.

Design/methodology/approach: This study applies the doctrinal method for examining the state asset management obtained from corporate criminal actions.

Findings: Several provisions for public accountants in Indonesia, such as public accountant law and accounting standards, have become the legal standing of the corporate area disclosure on audit report, but it has never been applied. However, the scandals of corporate financial manipulation can drag the public accountants on legal issues for their liability in minimizing and preventing the fraud and for strengthening the corrective justice role of the audit report.

Practical implications: There is a need for the empirical study to determine the effectiveness and the efficiency level for implementing the corporate disclosure on audit report. However, doctrinal research can be a comparison and can enrich empirical economic law for studying state asset management.

Originality/value: The study initiates to renew the audit report framework in Indonesia such as the formulation of vicarious liability explicitly in economic law and to establish an independent board that oversees the quality of audit reports, and assesses the performance and accreditation of public accountants.
\end{abstract}

Keywords: Public accountant, corporate, criminal, liability.

JEL code: G34.

Paper type: Research article.

\footnotetext{
${ }^{l}$ Faculty of Law, Diponegoro University, Semarang, Indonesia, email: henry.sinaga@pajak.go.id or sinagahenrydp@gmail.com

${ }^{2}$ Faculty of Law, Diponegoro University, Indonesia, e-mail: samektoadjifx@gmail.com

${ }^{3}$ Faculty of Law, Sriwijaya University, Indonesia, emai: joniemirzon@yahoo.co.id
} 


\section{Introduction}

Accounting and financial manipulations committed by certain big corporations for certain illegal purposes show that almost all their financial reports had been audited by public accountants. Some international cases had proved it, such as: Enron, which was audited by Arthur Andersen. This had caused investors, employees, and shareholders a lost of US\$74 billion; Waste Management, which was audited by Arthur Andersen, had reported false earnings amounting to US $\$ 1.7$ billion; WorldCom, which was audited by Arthur Andersen, had marked up assets amounting to US\$11 billion; and Lehman Brothers, which was audited by Ernst \& Young, had disguised the loan as the sales amounting to US50 billion (Tuanakotta, 2013). Arthur Andersen had been fined more than US\$100 million in 2001 for audit problems concerning two clients, Waste Management and Sunbeam (Chaney and Philipich, 2002). Moreover, several US-listed foreign companies had scandals in its audited financial reports, such as Royal Ahold Corporation (a Dutch company) which materially misrepresented its financial results and performance, Nortel Networks Corporation (a Canadian company) which inflated the demand for its products, growth in revenues, earnings, and market, and Lernout \& Hauspie Speech Products, N.V, a Belgian company) which made false and misleading statements. The scandals of several large companies, as its financial report have been audited, according to Soltani (2014) are the responsibility of public accountants. Based on the analysis of scandals of six audited corporates, namely, Enron, WorldCom, Royal Ahold, HealthSouth, Parmalat, and Vivendi Debacle, Soltani (2014) proved that the corporations as high profile lapses of accountability, lack of effective internal control mechanisms, and ineffective corporate governance structure, and the public accountants failed to maintain their independent conduct and made errors of judgement or created poor quality of audit.

Considering recurring cases carried out in over several past decades have caused significant financial losses to the victims, the limitation of regulation in formulating the corporate liability in criminal law level, and the legal meaning of manipulation (of accounting and of financial) has been formulated in the Decision of the Constitutional Court of the Republic of Indonesia Case Number 84/PUU-IX/2011 (2011) as "an action based on bad intention to illegally take advantage for oneself or for other party based on adequate initial evidences, it is urgent to study doctrinally about the public accountant legal liability in revealing the corporate criminal intent or guilty mind (mens rea) on an audited financial report". This background brings this article to focus on two main research questions. There have been several (comparative) research on the aspect of corporate actus reus, while attention for disclosing the corporate mens rea in corporate audit report as the public accountant legal liability has been rare. The existing researches are usually in separate focuses, between focusing on auditor legal liability and focusing on corporate liability. Two main research questions are; why public accountant must be legally liable to disclose the corporate mens rea and how are the implementation of the ideal corporate mens rea models on the public accountant report. 


\section{Public Accountant and Corporate Liability}

One of the most important pillars to account for and to communicate the company's performance to stakeholders periodically is financial statements as of financial information. Although some opinions state that financial statements cannot provide all the information needed by stakeholders, the purpose of financial statements must provide information regarding the financial position, performance, changes in financial position, and management accountability for the resources entrusted to it. Further, the information contained in the financial report must fulfill four qualitative characteristics, namely; understandable, relevant, reliable, and comparable (Institute of Indonesia Chartered Accountants, 2014).

The independent and accountable public accountant liability must express the corporate audit results that meet the understandable, relevant, reliable, and comparable characteristics. The audited financial statements affirm that between the public accountant as the independent auditor and the corporation as the auditee there is legal liability if there is an unlawful act in the financial statements, considering that each legal subject not only attaches the sanctions due to the violations committed but also to what is thought or for whom it is done. This is closely related to understanding liability, which is inherent in two obligations. Obligations due to the propriety of doing or acting and obligations due to appropriateness tpo do not act (Sinaga and Sinaga, 2018), where the outcome is being responsible for the good and harm that resulted by an act against the law (Honoré in Ewing, 2015). Herein, the meaning of illegal acts is not only limited to acts that violate the law but also acts that violate moral, propriety, thoroughness and caution that should be owned by someone in social life.

The relation between the corporate criminal liability who commits an illegal act in the scope of his business and the legal responsibility of a public accountant who has conducted an independent audit cannot be separated from the role of mens rea, as the fault element that establishes the "guilty mind" wrongdoer due to maxim actus non fit reus nisi mens sit rea (Chan and Simester, 2011) which must be clearly illustrated. This refers to some literature's view about the public accountant legal liability in determining auditee crimes on the audited financial report. Such Acemoglu and Gietzmann (1997) explained that in practice there seems to be some disagreement about the optimal size of public accountant liability because it will affect the contract of public accountant and audited corporation. If the public accountant liability is too low, the independence of the public accountant is not credible and if the public accountant liability is too high, the cost of auditing to corporate will increase. Nevertheless, it must be noted that the important commitment mechanism in ensuring the public accountant's independence, including to make them credible and do not collude with the corporation, is still in terms of the imposition of potential legal liability (punishment). Then, Kassem, Rasha and Higson (2016) more decisively concluded that public accountant is responsible for detecting material misstatements arising from corporate crime, but this role was not clearly defined 
relating to the limitations of audit standards. The firmness expressed by Kassem et al. (2016) also in line with Davison's (1982) opinion which stated that public accountant as auditor will be safe as long as a corporate as auditee is relatively honest.

However, no matter how strong the operational of auditee's internal control system exists there will be opportunities to manipulate financial results, and the public accountant will inevitably look bad for the dishonest of the auditee. So, in solving this Davison (1982) suggested the public accountant issue an adverse or a disclaimer opinion concerning its liability is not only for performing its own negligence and fraud of its duty but also for detecting the negligence and fraud of others, even though this would risk client displeasure and/or dismissal. Then, in terms of risks and legal liability of public accountant, Willekens et al. (1996) stated that the risk of public accountants' legal liability is of crucial importance, like the acceleration of litigation against auditors, and uncertainty over the scope and nature of auditors' legal liability. However, although auditors may be found to have been criminally liable under some circumstances, due to the major focus on negligence conduct of auditors, the auditors be held liable on the civil liability area. This is based on the reason that the uncertainty about the legal standard of 'due audit quality', as fundamental in understanding audit quality supplied, only decreases the quality of audit work supplied. However, if the legal standard of care were clear, there would be no role for audit standards due to the role of audit standards only to influence the behavior of public accountants.

It has been emphasized that corporate liability in a criminal act is supposed to more easily illustrated in the case that the corporate financial statements are audited by a public accountant because both of them have the respective responsibilities explicitly regulated. The existence of liability in which there are sanctions based on applicable laws and regulations shows that liability and sanctions are strongly related to the mens rea, which is the culpability principle refering to subjective mental attitudes as an important element in liability. As described mens rea as "connoting fault or blameworthiness of conduct, it should not be understood as synonymous with 'criminal intention' or 'wicked mind"' (The Malaysian Federal Court in Yeo, Morgan and Cheong, 2012). It can be said that the basic consideration of punishment is the deterrence of the offender who is only measured through mental statements that can be enforced, not based on actions or contributions in fulfilling a crime. The existence of such negligence is an entry point of understanding that not all parties to a crime are considered equally responsible, but are based on each individual who is considered guilty of all collective crime outcomes that refer to the reprehensible mental attitude that arises in the intention to take part (Steer, 2017).

Furthermore, the proof of corporate mens rea is relatively very difficult, as Graycar (2016) revealed that the criminal behavior, by means of institutions, workplaces, and cultures, is part of the system in not only for many poor-countries but also surges certain developed countries, which shows that the problem of corporate mens rea lies 
in the prevailing institutions, as a problem of collective action. The corporate abuse as tools of financial crimes engineering should be tackled in establishing trustworthy and impartial institutions (Rothstein, 2011) by proving the corporate mens rea, while the existing adequate models are the anthropomorphic models (also known as the derivative models) and the organizational models, as the necessary connection in constructing the scheme of liability for the organizational fault (Colvin, 1995).

The next assertion due to corporate and individual liability within two models of corporate mens rea have been proposed by several scholars, such as Colvin (1995), Lord Denning (in de Maglie, 2005), de Maglie (2005) and Gobert (1994). Colvin proposed about the necessary connection between corporate and individual liability in constructing the scheme of liability for an organizational conduct and fault, which the scheme should construct the corporate mens rea into the derivative (or the anthropomorphic) and the organizational models. The understanding of anthropomorphic is based on the attribution of human characteristics to other creatures, as Lord Denning equates a corporation with a human body that has a brain and nerve center, which can control what it wants to do. Corporations are considered to have a hand that holds a tool and acting in accordance with instructions from the center, where core corporate management, such as the board of directors, are considered as the mind and will of the corporation that controls what needs to be done in the company. While agents or employees in the company mere servants and agents who are no more than hands to do work and who are considered to act, so they cannot be said to represent the mind or the will of the core corporate management. It means, the anthropomorphic models measure the corporate blameworthiness based on individual culpability, which are assumed that all legally or illegally conducted by core corporate management will be automatically identified as corporate activities. All the conduct of core corporate management are not as the corporate agents, but as the corporate itself. The related explanation about the anthropomorphic models expresses that the identification doctrine or the alter ego doctrine or vicarious liability is considered fulfilling the anthropomorphic models requirement, which indeed relates to derivatives of the individual liability (Colvin, 1995). The anthropomorphic understandings which have been proposed by Colvin, Lord Denning and de Maglie, also in line with Gobert opinion which stated that the mental state (mens rea), which is deemed to justify a finding of blameworthiness of a corporation will be based on the offenses of one person that is attributed to corporation (Gobert, 1994) occurring in the course of corporation's business.

The shift to corporate's liability is the other responsibility form of corporations to anticipate potential dangers and/or to prevent potential risks. The shift of liability from individual to corporate is based on several sides, like vicarious liability principle, identification theory, and aggregation concept (Gobert, 1994). Hereinafter, the organizational model is described by de Maglie (2005) as the implementation of the corporate criminal liability based on its characteristics, policies, and practices. Furthermore, Colvin (1995) elucidated the organizational model as the law of corporate criminal liability within fulfilling two fundamental frameworks. First, the 
duty upon corporations toward their risk operations, structures, and resources that may cause harm or may be used to cause harm. Second, the corporate culture within the corporation must be of significance.

\section{Corporate Criminal Liability in Accounting Practice}

In believing the accountability, the truth and the appropriateness of financial statements information, an audit needs to be carried out. This is generally possible to be done in 2 audit forms, namely external audit, carried out by public accountants as independent double-check financial statements, and internal audits, which plays a role in determining the effectiveness and support of the organization's internal reporting system. Or in other meaning, in proving that the corporation is responsible for its assets, entities, procedures, or processes, the corporation must make the audit the central point of its accountability, as O'Reagan (2004) argued "without audit, no accountability, without accountability, no control, and if there is no control, where is the seat of power?". Through periodically audits, especially for certain corporations that have been obliged to be audited by a public accountant, the public accountant must be responsible for the consequences of each audit that they do, as Article 26 of the Public Accountant Law asserts the liability of public accountant on their services. So that, Public Accountants must maintain their independence and must be free from conflicts of interest in providing audit services (Article 28 of the Public Accountant Law). The consequences of violating legal obligations for public accountant in Indonesia cause legal consequences, which have been strictly regulated in the form of administrative and criminal sanctions in Public Accountant Law.

In Accordance with Article 53 of the Public Accountants Law, the administrative sanction is imposed on Public Accountants, Public Accounting Firms and/or branches of the Public Accountant Office. Such sanctions are recommendations to carry out certain obligations, warning letters, restrictions on the provision of services to certain entities, restrictions on granting certain services, freezing of licenses, revocation for licenses, and/or fines. Whereas Article 55 (criminal against Public Accountants) and Article 56 (criminal against Associated Parties) of the Public Accountant Law strictly regulate the criminal provisions for Public Accountant and Associated Parties who: (1) manipulating, helping to manipulate, and / or falsify data relating to services provided; or (2) deliberately manipulating, falsifying, and / or removing data or notes on working paper or not making working papers relating to services provided so that those working papers cannot be used properly in the framework of inspection by the authorized party. However, specifically for the Public Accountant Law who violates Article 55, they will be exempt from criminal charges if those actions have exceeded 5 (five) years from the date on service provision report.

The command of law for public accountants is to relies on audit result, to keep the independence, to meet on four qualitative characteristics requirement in audit report, and to meet the stakeholders interest on information that corporations disclose, on 
the trustworthiness of the disclosure, and how the information is disclosed (Benston, et al., 2003) are the undeniable legal basis for public accountants compliance in conducting a corporate audit (Nasution, 2014). So that, the public accountant must comply the Professional Standards of Public Accountant of Indonesia (Standard Profesional Akuntan Publik-SPAP) as the measure of quality that must be obeyed by public accountants in the provision of services, as mandated under Article 1 point (1) of Association Regulation of Indonesian Institut of Certified Public Accountants (Institut Akuntan Publik Indonesia - IAPI) Number 3 of 2017 regarding Professional Standards of Public Accountant. The SPAP is very concerned about fraud and compliance to regulation, so there are several important audit aspects that must be met, such as the implementation of risk-based audit, principles-based standard, and professional judgment and skepticism, the reduction of mathematics model approach, and the involvement of experienced and qualified auditors.

Actually, this Indonesian SPAP is not as excellent as the newest audit standards of the Public Companies Accounting Oversight Board (PCAOB) and the International Auditing and Assurance Standards Board (IAASB) in the United States or Europe. As in June 2017, the PCAOB adopted AS 3101 as a new audit reporting standard that change auditing from the culture emphasis to public service emphasis, which the primary goals are to make the auditor's report easier to read, to assert the liability of auditor while conducting the audit, and to provide additional information to report users. In AS 3101, the auditors are required to discuss the so-called "critical audit matters" (CAMs) within their reports. According to Clikeman, the term CAMs in PCAOB is similar to the term of "key audit matter" in IAASB located within International Standard on Auditing (ISA) 701. CAMs, as defined in AS 3101.11, is "any matter arising from the audit of the financial statements that was communicated or required to be communicated to the audit committee and that: (1) relates to accounts or disclosures that are material to the financial statements and (2) involved especially challenging, subjective, or complex auditor judgment, while "key audit matters" disclosed in European audit reports include revenue recognition, recoverability of goodwill, loan loss reserves, and litigation provisions (Clikeman, 2018).

Further, Clikeman (2018) recommended the factors alone or in combination in determining whether an audit decision meets the AS 3101 criterion (1) the auditor's assessment of the risks of material misstatement, including significant risks, (2) the degree of auditor judgment related to areas in the financial statements that involved the application of significant judgment or estimation by management, including estimates with significant measurement uncertainty, (3) the nature and timing of significant unusual transactions and the extent of audit effort and judgment related to these transactions, (4) the degree of auditor subjectivity in applying audit procedures to address the matter or in evaluating the results of those procedures, (5) the nature and extent of audit effort required to address the matter, including the extent of specialized skill or knowledge needed or the nature of consultations outside the 
engagement team regarding the matter; and (6) the nature of audit evidence obtained regarding the matter.

In carrying out the duties and liabilities in accordance with applicable provisions in Indonesia, the public accountant liability should concern some developed countries which have adopted the PCAOB and the IAASB that made a breakthrough in terms of audit reporting. It is supposed to be a legal obligation for Indonesian public accountants to disclose critical information about the mechanisms and procedures for the liability of the parties in the audited corporation which is a reflection of the depiction of corporate mens rea in an unlawful conduct. The urgency of mens rea, both to corporations and to public accountants in matters of unlawful conduct, shows that the implementation of liability will prevent, supervise, and evaluate of the unlawful objects, because the corporation as an auditee and the public accountant as an independent auditor disclose the obligation for its propriety to act or not to act.

Indeed, the implementation of corporate mens rea has been criticized for the emergence of problems, both theoretically and practically. Theoretically, the problem refers to the absence of corporate facilities such as the characteristics that are owned by humans who deserve to have mens rea characteristic. While the practical problems related to the assumption of imposing the corporate mens rea that will hamper the work of regulation which forced to assess the legal behavior of the collection of people. However, the assumption about the problems of adopting corporate mens rea can be refuted concerning the variety of modern decentralized corporations, when handling the occur violations must be carried out as an integrated entity that must be attributed to corporations due to its impossibility to prove the guilty minds of the individuals in a corporation (de Maglie, 2005). Another supporting opinion is put forward by emphasizing the existence of a distinctive role played by corporations and individuals, which when reviewed against individuals will be obtained by the fact that the occurrence of individual violations is due to corporate coercion, both in forms of encouragement/support and/or tolerance, which are carried out in order to carry out and achieve the tasks set by the corporation. This corporate mens rea is the prerequisite of a corporation before bearing blameworthiness for the consequences of corporate conducts (Chan and Simester, 2011).

\section{Corporate Mens Rea Formulation on the Public Accountant Report}

PERMA Number 13 of 2016, Regulation of General Attorney General Number PER-028 / A / JA / 2014, and several special laws have formulated the corporate criminal liability and its sanctions types. However, how to prove the corporate mens rea in terms of corporate liability, referring to the existence of a corporate obligation due to its appropriateness to act and its propriety do not act, still cannot be fully implemented in practice given the limited rules in corporate criminal law in Indonesia and the absence of existing corporate governance models, the anthropomorphic and the organizational models. The Article 4 paragraph (1) and (2) 
of the PERMA Number 13 of 2016 embodies the legal standing of the corporate and / or the corporate management mens rea in the form of certain corporate interests and corporate interests from the occurrence of the crime, the omission of a criminal act in the scope of the corporation, and the absence of the corporation in taking the appropriate precautions for avoiding or reducing the crime impacts. This Article 4 paragraph (1) and (2) of the PERMA Number 13 of 2016 supposed to be reinforced through the existing mens rea proof models, the anthropomorphic models and the organizational models. Then it can be used as the strength of law enforcers to further prove the corporate crime.

The implementation of the anthropomorphic model that should be based on certain doctrines, such as identification doctrine, alter ego doctrine, and aggregation doctrine, are the proper guidence to use vicarious liability in proving the individual unlawful acts as the basis of corporate criminal liability. The identification doctrine guideline base, alter ego doctrine, and aggregation doctrine as the right of vicarious liability refers to a general principle that transfers the core responsibility (or high) of corporate management to corporate governance, which is the corporate control and care towards its employees (Sinaga, 2017a).

The following explanation describes the meaning of identification doctrine, alter ego doctrine, and aggregation doctrine which relates to vicarious liability. The identification doctrine shows the existence of one economic unit between individuals and their organizations based on existing interpretations or contracts, so that the rights and obligations of one party can be attributed to the other parties in the organization. Indeed, there can be problems with the interpretation of contracts or regulations in this doctrine in terms of the emergence of a legal problem whose purpose is to ignore and deny the corporate liability (Vandekerckhove, 2007\). While the alter ego doctrine is the reflection of vicarious liability or respondeat superior concerning the attribution of the mental state of high (or core) corporate management to the corporate mental state (Leigh, 1982) because of the occurrence of an illegal act carried out by high/core corporate management is inseparable from strong corporate dominance, including in financial issues, corporate policy, and corporate practical business (Bergkamp and Park, 2001\). When one or more high corporate core management commit illegal acts, those high/core corporate management are the corporate alter ego (Gómez-Jara Díez, 2011). Then, related to the aggregation doctrine, Hornman and Sikkema (2015〉) categorized this doctrine as the combination of the derivative model and the organisational models that could provide a convincing theoretical foundation for corporate mens rea due to all the acts and mental elements of the various relevant persons within the corporation are combined, to ascertain whether in total they would amount to a crime if they had all been committed by one person. Hornman and Sikkema compared the aggregation doctrine with the 'scraping together' method due to the intentions of several individual employees that cannot be split up and divided amongst its members, so based on the corporate structure which serves as the frame upon the attitudes of the 
participating individuals, these intentions are interwoven to form the corporate intentions.

The challenges of the derivation of individual criminal liability through corporate management become corporate criminal liability as a form of the anthropomorphic model, are based on the argument that the management is not the corporation's "mind". However, Friedman (1979) argued that it is at least as part of corporate conscience which has the ability to authorize, to request, to command, to perform or to tolerate, which in general is a level of mens rea of several countries' criminal reasoning codes, such as Singapore which applies terms of intention, knowledge, rashness, negligence, dishonesty, fraudulently, and voluntarily (Yeo, Morgan and Cheong, 2012), or Australia which applies terms, knowledge, recklessness or negligence. Other opinions that represent core or high corporate management actions as a corporate act, among others, were stated by Bergkamp and Park (2001), Parker (1996) and several other countries although in other terms. Such as Australia and New Zealand terms with corporate "controlling officers" as the persons participating in the control of the corporation in the capacity of a director, manager, secretary or other similar officer (whether or not they were, or were validly, appointed to any such office position), and the American Law Institute's Model Penal Code in the term "board of directors" or any "high managerial agent" as a person acting on behalf of the corporation (Colvin, 1995).

Several opinions that represent the core (high) corporate management actions as corporate actions affirm that the anthropomorphic models in line with Indonesian penal code formulation which regulates that the perpetrator may only be punished based on the legality principle for the basis of crimes and on the fault principle the basis of punishability. It also means that based on the appropriateness and the reasonableness of the anthropomorphic models, both the legal entity and the human can be criminally liable jointly and/or independently as long as the person has the function in the organizational structure, or acts on behalf of corporate, or based on employment relationship in the scope of such corporate (Sinaga, 2017).

The organizational models as more interventionist measures to control corporate externality-creating behavior were firstly proposed by Christopher Stone in his book, "Where the Law Ends: The Social Control of Corporate Behavior" in 1975. Stone initiated the corporate mens rea through public directorships and governmentally imposed internal corporate procedures, modeled on the organizational structure and procedures of corporate administrative agencies (Parker, 1996). In modern literature on corporate criminal liability, the use of organizational models in proving the corporate mens rea is clearer than the useful of anthropomorphic models. The organizational models have not been "personated", as Friedman (1979) has examined its two major areas and other reasons are argued by Hornman and Sikkema (2015). 
Contrary to the excellence of this organizational model, Hornman and Sikkema (2015) also criticized its difficulty to prove such organisational fault, for example, to relate the illegal acts conducts with the certain culture or unwritten rules and policies which existed within a corporation. The public accountant's legal liability to disclose the corporate mens rea in its audit report must be concise, brief and clear, especially regarding the details of the parties liable in the corporation, corporate characteristics, corporate governance policies and practices, corporate legal implementation and control, legal culture, constraints faced when audits were carried out, etc. Due to enthusiasm for tackling accounting and financial manipulation, as for fulfilling those four qualitative characteristics of financial statements and to meet the requirement on the accounting standards and SPAP, several ways are worth considering such as revealing non-financial information, as the performance measurements that are not expressed in monetary units, on the financial report. Indeed, the role of public accountants in providing nonfinancial information is still hotly debated, which refers to three main reasons, increased audit costs and increased litigation risk due to the broad scope of audits on non-financial information, the concern of auditor's opinion on the financial statement, while the auditors supposed not be responsible for auditing non-financial measures is the potential to confuse financial statement users, the stakeholders are likely to become overwhelmed by the overloaded information.

However, due to the obligation of auditor in understanding the measurement procedures, management practices, systems, and integrity of the third-party organizations, as long as it does not undermine the credibility of the audited financial statements, and due to prevailing rules and the rampant of misusing corporations as tools of financial crime, it must be a necessity to report non-financial information. The great benefits to stakeholders regarding to non-financial information disclosure on audit report had been released by PCAOB (Murphy and Hogan, 2016), in the form of the increased ablity in understanding the nature and scope of the auditor's responsibilities with respect to the other information, the clarification as to what other information was evaluated by the auditor, and description of the results from the auditor's evaluation of other information. There is also a form of accumulating the evidence in the form of testimonial evidence, documentation evidence, physical evidence, and personal observations to make sure whether is there an element of fraud in the financial statements of a corporation and Building an independent board that insist on maintaining high audit standards, on enforcing of accounting standards (Benston et al., 2003), on controlling of public accountants' performance, and on evaluating of public accountants' accreditation.

\section{Conclusion}

The description of corporate mens rea models on the public accountant report has never ben applied even though there are several provisions, such in the Public Accountant Law, in the SPAP, and in the accounting standards, which become the legal standing of its implementation. Although public accountants could be criminally liable under some circumstances, the uncertainty about liability rules on 
audited financial report, both to the public accountant and the corporation, the uncertainty about liability rules on audited financial reports, both of the public accountant and the corporation, are one of the causes of the widespread accounting and financial manipulation for the unlawful act's purpose. Significant changes are needed in the audit reporting system which can anticipate intentions to unlawful conduct, from the repressive actions to preventive actions, by disclosing the nonfinancial information critically in the audited report.

The non-financial information which reveals the anthropomorphic and the organizational models must be briefly and clearly revealed, including the disclosure of details of the parties responsible for the corporation, the characteristics, policies, and practices in corporate governance, implementation, and control of corporate legal culture, constraints faced when audits are carried out, etc, which are reflections for facilitating the corporate mens rea verification when problems arise. In this case, it can be evaluated more easily on public accountants who really have carried out their duties and liabilities independently. With the disclosure of the nonfinancial information on the audit reports, positive results for public accountants were obtained such the stronger independence and integrity as well as better levels of prudence and expertise, while the positive results for corporations are to anticipate potential dangers and/or prevent potential risks related to unlawful acts.

\section{References:}

Acemoglu, D. and Gietzmann, M.B. 1997. Auditor Independence, Incomplete Contracts and the Role of Legal Liability. European Accounting Review, 6(3), 355-375.

Benston, G., Bromwich, M., Litan, R.E. and Wagenhofer, A. 2003. Following the Money: The Enron Failure and the State of Corporate Disclosure. AEI-Brookings Joint Center for Regulatory Studies, Washington, D.C.

Bergkamp, L. and Park, W.Q. 2001. Piercing the Corporate Veil: Shareholder Liability for Corporate Torts. Maastricht Journal of European and Comparative Law, 8(2), 167188.

Chan, W. and Simester, A.P. 2011. Four Functions of Mens Rea. Cambridge Law Journal, 70(2), 381-396.

Clikeman, P.M. 2018. AS 3101: The PCAOB's New Auditor Reporting Requirements. The Journal of Corporate Accounting \& Finance, 29(3), 7-15.

Colvin, E. 1995. Corporate Personality and Criminal Liability. Criminal Law Forum, 6(1), 144.

Davison, A.G. 1982. Auditors' Liability to Third Parties for Negligence. Accounting and Business Research, 12(48), 257-264.

De Maglie, C. 2005. Models of Corporate Criminal Liability in Comparative Law. Washington University Global Studies Law Review, 4(3), 547-566.

Ewing, B. 2015. The Structure of Tort Law, Revisited: The Problem of Corporate Responsibility. Journal of Tort Law, 8(1/2), 1-28.

Friedman, H.M. 1979, Some Reflections on the Corporation As Criminal Defendant. Notre Dame Law Review, 55(2), 173-202.

Graycar, A. 2016. Corruption and Public Value. Public Integrity, 18(4), 339-341.

Gobert, J, 1994. Corporate Criminality: Four Models of Fault. Legal Studies, 14(3), 393-410. 
Gómez-Jara Díez, C. 2011. Corporate Criminal Liability In The Twenty-First Century: Are All Corporations Equally Capable of Wrong doing? Stetson Law Review, 41, 4161.

Hornman, M. and Sikkema, E. 2015. Corporate Intent: In Search of a Theoretical Foundation for Corporate Mens Rea. In de Jong, F., Vervaele, J.A.E., Boone, M.M., Kelk, C., Koenraadt, F.A.M.M., Kristen, F.G.H, Rozenblit, D., Sikkema, E, (Eds.), Overarching views of delinquency and deviancy. Pompe, Reeks, 287-309.

Institute of Indonesia Chartered Accountants. 2014. Effective Financial Accounting Standards 1 January 2015, Indonesian Institute of Accountants, Jakarta.

Kassem, A., Rasha and Higson, 2016. External Auditors and Corporate Corruption: Implications for External Audit Regulators. Current Issues in Auditing, 10(1), 110.

Leigh, L.H. 1982. The Criminal Liability of Corporations and Other Groups: A Comparative View. Michigan Law Review, 80(7), Articles on Corporate and Organizational Crime, 1508-1528.

Murphy, L. and Hogan, R. 2016. Financial Reporting of Nonfinancial Information: The Role of the Auditor. The Journal of Corporate Accounting \& Finance, 28(1), 42-49.

Nasution, B. 2014. Structure of Independence of the Financial Services Authority. Journal of Law and Justice, 3(3), 281-294.

O’Regan, D, 2004. Auditor's Dictionary: Terms, Concepts, Processes, and Regulations. John Wiley \& Sons, New Jersey.

Paul, K., Chaney, P.K. and Philipich, K.L. 2002. Shredded Reputation: The Cost of Audit Failure. Journal of Accounting Research, 40(4), 1221-1245.

Parker, J.S. 1996. Doctrine for Destruction: The Case of Corporate Criminal Liability. Managerial and Decision Economics, 17(4), 381-398.

Rothstein, B. 2011. Anti-Corruption: The Indirect 'Big Bang' Approach. Review of International Political Economy, 18(2), 228-250.

Sinaga, H.D.P. 2018. Reorientation of Tax Legal Certainty in Indonesia: An Exploration of Transcendental Law. Advances in Social Science, Education and Humanities Research, 192, 282-287.

Sinaga, H.D.P. 2017a. Substitute Liability in Tax Law in Indonesia. Legal Issues, 46(3), 206-217.

Sinaga, H.D.P. 2017b. The Criminal Liability of Corporate Taxpayer in the Perspective of Tax Law Reform in Indonesia. Mimbar Hukum, 29(3), 542-557.

Sinaga, H.D.P. and Sinaga, B.R.P. 2018. Reconstruction of Taxation and Customs Liability Models. Canisius, Yogyakarta.

Soltani, B. 2014. The Anatomy of Corporate Fraud: A Comparative Analysis of High Profile American and European Corporate Scandals. Journal of Business Ethics, 120(2), 251-274.

Steer, C. 2017. Translating Guilt: Identifying Leadership Liability for Mass Atrocity Crimes. Asser Press and Springer Science+Business Media B.V., The Hague.

Tuanakotta, T.M 2013. Detect Financial Statement Manipulation. Jakarta, Salemba Empat.

Vandekerckhove, K. 2007. Piercing the Corporate Value. Kluwer Law International.

Willekens, M., Steele, A. and Miltz, D. 1996. Audit Standards and Auditor Liability: A Theoretical Model. Accounting and Business Research, 26(3), 249-264.

Yeo, S., Morgan, N. and Cheong, C.W. 2012. Criminal Law in Malaysia and Singapore. LexisNexis, Singapore. 